\title{
Genetic Variability, Heritability and Genetic Advance Estimates in Some Maize (Zea mays L.) Varieties in Sudan
}

\author{
Mohammed A. Mohammedali ${ }^{1}$, Omer A. Mohamed ${ }^{1, *}$, Mohielden G. Abdalla ${ }^{2}$, Kamaleldin A. M. A. \\ Taha $^{2}$, Esam Mahgoub M. Ahmed ${ }^{1}$ \\ ${ }^{1}$ Department of Agronomy, Faculty of Agriculture, Omdurman Islamic University, P.O. BOX 382, Sudan. \\ ${ }^{2}$ Department of Horticulture, Faculty of Agriculture, Omdurman Islamic University, P.O. BOX 382, Sudan.
}

\begin{abstract}
How to cite this paper: Mohammed A Mohammedali, Omer A. Mohamed, Mohielden G. Abdalla, Kamaleldin A. M. A. Taha, Esam Mahgoub M. Ahmed. (2021) Genetic Variability, Heritability and Genetic Advance Estimates in Some Maize (Zea mays L.) Varieties in Sudan. International Journal of the Science of Food and Agriculture, 5(1), 85-90.

DOI: $10.26855 /$ ijfsa.2021.03.012
\end{abstract}

Received: December 27, 2020

Accepted: January 24, 2021

Published: February 5, 2021

*Corresponding author: Omer A. Mohamed, Department of Agronomy, Faculty of Agriculture, Omdurman Islamic University, P.O. BOX 382, Sudan.

Email: omerbz99@gmail.com

\begin{abstract}
An experiment was conducted during winter season 07/2008. Twenty five maize varieties for ten traits were studied in randomized complete block design (RCBD) with three replications at the field of experiments of the Faculty of Agriculture, Sudan University of Science and Technology in Khartoum (Shambat) Sudan to estimate the magnitude of their genetic variability, heritability and genetic advance for yield and yield components were studied plant height $(\mathrm{cm})$, ear height (cm), fresh ear weight dehusked (g), number of husk leaves, dry ear weight (g), ear length $(\mathrm{cm})$, number of rows per ear, number of kernels per row, weight of hundred kernels (g), and grain yield ( $\mathrm{kg} / \mathrm{ha})$. Analysis of variance revealed significant differences for most characters studied among the varieties. The phenotypic coefficient of variation (PCV) is higher than genotypic coefficient of variation (GCV) recorded for all traits. The highest heritability and high value (64.29\%) was found for number of husk leaves followed by ear height (60.29\%), moderate heritability estimates were observed for plant height (51.74\%), fresh ear weight dehusked (46.91\%) and ear length (39.29\%). Genetic advane as percent of mean was the highest for ear length (51.04) and weight of hundred kernels (20.49) indicating additive gene action for these traits. The information generated from this study, maize breeder can be exploited for future maize breeding programs.
\end{abstract}

\section{Keywords}

Maize, Variability, Heritability and Genetic Advance

\section{Introduction}

Maize also name Corn (Zea mays L.) is a grain crop that belongs to the family Poaceae, it has great yield potential and attained the leading position among cereal based on production as well as productivity and that is why it is called "queen of cereals" [1]. Maize is the third most important food crop of the world, after wheat and rice, providing $15 \%$ of the protein, and $19 \%$ of the calories for the developing countries [2]. In the Sudan maize is the fourth cereal crop after sorghum, wheat and millet [3]. Maize is a multipurpose crop, provides food for human, feed for animals and poultry, and fodder for livestock. It is a rich source of raw materials for industry. Also, maize is an important source of calories and protein in human lives in many countries of the world and is the main staple food in Africa particularly in eastern Africa [4]. In the Sudan, Maize grown in small scales under rainfed conditions in Kordofan, Darfour, and Southern states, under irrigation in Northern States and under flood irrigation in Kassala State [5]. Grain yield is affected by genotype and environmental factors because of its quantitative properties. Effectiveness of selection is dependent upon the 
availability of large genetic variability present in the breeding material for the target character and the extent to which it is heritable, it also depends on the direction and magnitude of association between the traits to be improved [6]. Genetic variability in a crop population is important for successful plant breeding. The success of any plant breeding program depends on the genetic variability and selection skill of plant breeder [7]. The mean values, genotypic and phenotypic variances, heritability, and the genetic advance of agronomic traits are some of the key parameters which determine the efficiency of a breeding program. The phenotypic variance explicates the total variance among phenotypes tested in different environments of interest to the plant breeder while the total genotypic variance explains the portion of phenotypic variance attributable to the failure of homogeneity among genotypes in different environments [8]. Heritability of a metric character is one of its important properties, and this expresses the proportion of the total variance that is attributable to the average effects of genes, and this is what determines the degree of resemblance between relatives. Heritability estimates allow breeders to develop more efficient selection strategies and to predict Heritability alone provides no indication of the amount of genetic improvement that would result from selection of individual genotypes. Hence knowledge about genetic advance coupled with heritability is most useful. Character exhibiting high heritability may not necessarily give high genetic advance. Heritability value alone may not provide clear predictability of the breeding value. Heritability in conjugation with genetic advance over means (GAM) is more effective and reliable in predicting the resultant effect of selection. GA is also of considerable importance because it indicates the magnitude of the expected genetic gain from one cycle of selection [9].

The Phenotypic and genotypic coefficients of variation (PCV and GCV) are used to determine the extent of variability among traits of crops and are essential in selecting polygenic yield determining traits [10]. Therefore, the present study was carried out to assess the extent of genetic variability, heritability and genetic advance among maize varieties for yield and its components for efficient design of maize breeding schemes.

\section{Methods}

\subsection{Experimental site}

This experiment was carried out in the field of the College of Agricultural Studies, Sudan University of Science and Technology, Shambat, Sudan, during the winter season, 07/2008. It was located at latitude of 15\$,0longitude of $32^{\circ} 32^{\prime \prime} \mathrm{E}$, and altitude $386 \mathrm{~m}$ above sea level. The soil was clay soil with a $\mathrm{pH}$ in the range of 7.8-8.5.

\subsection{Plant materials}

The genetic material used in this study consisted of twenty three open pollinated maize varieties obtained from CIMMYT in addition to two local varieties viz Mugtama-45 and Var.113 presented in Table 1.

\subsection{Cultural Practices}

Before plowing, experiment land was cleaned from remains of previous crop, and then plowed with Disc Plow, a deep plow of $35 \mathrm{~cm}$, after making sure that the land is suitable for agriculture and of appropriate humidity, after that dirt blocks were broken and soil was rotovating by Disc harrow. After that leveling land using a scrapper, and before planning soil with Ridger, process of spreading phosphate fertilizer, planning process was carried out with a distance of 80 $\mathrm{cm}$ between the moth and the other.

\subsection{Method of sowing}

Planting was done manually in holes on upper third of line by placing three grains in each bush with a depth of 3-5 $\mathrm{cm}$ with a distance of $80 \mathrm{~cm}$ between lines and $25 \mathrm{~cm}$ between plants. Thinning was carried out two weeks after seedling emergence to one plant per hill. A dose of fertilizer application, $2 \mathrm{~N} \mathrm{(100} \mathrm{kg/ha)} \mathrm{was} \mathrm{added} \mathrm{in} \mathrm{split} \mathrm{dose} \mathrm{after} \mathrm{emer-}$ gence of two weeks and before flowering. Hand weeding was done to keep the plot free of weeds. irrigation process was carried out immediately after planting by adding a sufficient amount of water and then irrigation rolled after first at a rate of (6-10) days until weaning after ripening of grains, which ranged between (110-120) Days of cultivation.

\subsection{Data observation}

Observations were taken on randomly selected 10 plants from each experimental plot for all the traits under consideration included, plant height $(\mathrm{cm})$, ear height $(\mathrm{cm})$, fresh ear weight dehusked $(\mathrm{g})$, number of husk leaves, dry ear weight $(\mathrm{g})$, ear length $(\mathrm{cm})$, number of rows per ear, number of kernels per row, weight of hundred kernels (g), and grain yield (kg/ha).

\subsection{Statistical analysis}

The experiment was carried out in Randomized Complete Block Design (RCBD), with three replicates, data collected on all the traits studied were subjected to analysis of variance (ANOVA) according to [11], using statistical software, M-STAT-C. 
Table 1. List of twenty five varieties used in the study

\begin{tabular}{ccc}
\hline Number & Variety & Source \\
\hline 1 & S03SLW-LE & CIMMYT \\
2 & S03SIW & CIMMYT \\
3 & S03SIW-HG"A" & CIMMYT \\
4 & S03SIW-HG"AB-2" & CIMMYT \\
5 & S03SLW-MBR-1 & CIMMYT \\
6 & S02WQ-Q27*TX & CIMMYT \\
7 & ACROOS-2G27WQ & CIMMYT \\
8 & ACROSS-02G27WQ-1 & CIMMYT \\
9 & ACROSS-02SIWQ & CIMMYT \\
10 & TLALTIZAPAN9944 & CIMMYT \\
11 & ACROSS-02[TX*TX] & CIMMYT \\
12 & ACROSS-02[284/176] & CIMMYT \\
13 & HYDERABAD97502 & CIMMYT \\
14 & Var.113 & ARC \\
15 & S03SIY-1 & CIMMYT \\
16 & S03SIY-2 & CIMMYT \\
17 & S03SIY-MBR & CIMMYT \\
18 & ACROSS-S00HGY-"B" & CIMMYT \\
19 & S02G29YQ & CIMMYT \\
20 & ACROSS-S02G29YQ & CIMMYT \\
21 & TLATIZAPAN.02G29YQ & CIMMYT \\
22 & S02SIYQ & CIMMYT \\
23 & TLATIZAPAN9735 & \\
24 & SIMMYT \\
\hline & & \\
\hline
\end{tabular}

Source: ARC-Agricultural Research Corporation, Sudan.

\subsection{Estimation of variance components}

Variance components were estimated to identify genetic variability among vareities. Error $\left(\sigma^{2} \mathrm{e}\right)$, genotypic $\left(\sigma^{2} g\right)$ and phenotypes $\left(\sigma^{2} p\right)$ variances were calculated from expected mean squares of analysis of variance by adopting the formula suggested by [12].

where: $\mathrm{MSe}=$ mean square of error

$$
\text { Error variance } \sigma^{2} \mathrm{e}=\text { MSe }
$$

Genotypic variance $\sigma^{2} \mathrm{~g}=(\mathrm{MSg}-\mathrm{MSe}) / \mathrm{r}$

where: $\mathrm{MSg}=$ mean square of genotype, $\mathrm{MSe}=$ mean square of error and $\mathrm{r}=$ number of replications

$$
\text { Phenotypic variance } \sigma^{2} \mathrm{ph}=\sigma^{2} \mathrm{e}+\sigma^{2} \mathrm{~g}
$$

where: $\sigma^{2} \mathrm{e}=$ error variance and $\sigma^{2} \mathrm{~g}=$ genotypic variance

\subsection{Phenotypic and genotypic coefficient of variation}

The estimates of phenotypic and genotypic coefficient of variation were calculated as described by [13].

$$
\begin{aligned}
& \text { PCV\% }=\sqrt{ } V \mathrm{p} / X \\
& \text { GCV\% }=\sqrt{ } \mathrm{Vg} / \mathrm{X}
\end{aligned}
$$

where: PCV is phenotypic coefficient of variance, Vp is phenotypic variance, $\mathrm{X}=$ Grand mean of a trait. GCV is geno- 
typic coefficient of variance, and Vg is genotypic variance. GCV and PCV values were categorized as low (0-10\%), moderate (10-20\%), and high (20\% and above) as indicated by [14].

\subsection{Heritability}

It was estimated as the ratio of total genotypic variance to the phenotypic variance according to [15]:

$$
\mathrm{H}^{2}=\mathrm{Vg} / \mathrm{Vp} \times 100
$$

where: $\mathrm{H}^{2}=\%$ Broad sense heritability. The heritability percentage was categorized as low (0-30\%), moderate (30-60\%), and high $\geq 60 \%$ as described by [16].

\subsection{Genetic advance}

Genetic advance (GA) was estimated using the formula by [13]:

$$
\text { Genetic Advance }(\mathrm{GA})=\mathrm{H} \times \mathrm{ph} \times \mathrm{K}
$$

where: $\mathrm{H}$ is heritability, ph is phenotypic standard deviation, and $\mathrm{K}$ is selection deferential (2.06 at $5 \%$ ).

Genetic Gain (\%) = GA × 100; it is categorized as low (0-10\%), moderate $(10-20 \%)$ and high $(20 \%$ and above) as described by [16].

The genetic advance as a\% of the mean (GAM) was calculated as:

$$
\mathrm{GAM} \%=\mathrm{GA} / \mathrm{X} \times 100
$$

where: GA = Genetic advance and $\mathrm{X}=$ Grand mean of a trait.

\section{Results}

Analysis of variance showed highly significant value at $1 \%$ probability for most of traits studied viz, plant height , ear height, fresh ear weight dehusked, number of husk leaves, ear length and except number of rows per ear showed significant at $5 \%$ probability. The mean sum of square due to varieties, replications and error are presented in Table 2 . Thus, the genetic variability recorded in this study could be exploited by plant breeders to develop varieties.

Genetic parameters of yield and their components are given in Table 3. In the present study, the highest genotypic variance were observed for grain yield $(432,418.19)$ and fresh ear weight dehusked $(303.01)$ while the lowest genotypic variance was found for number of rows per ear (0.13) and weight of hundred kernels (0.41). The highest phenotypic variances were for grain yield $(3,122,322.47)$ followed by fresh ear weight dehusked $(645.99)$ while the lowest were for number of rows per ear (0.58) and ear length (1.12). The highest environmental variance was found for grain yield $(2,689,904.28)$ and fresh ear weight dehusked (342.98) while lowest was found for number of husk leaves $(0.40)$ and number of rows per ear (0.45). Phenotypic variances were greater than the genotypic variances.

Genotypic coefficient of variation(GCV) was the highest in case of fresh ear weight dehusked (10.98) and ear height (9.54) while lowest genotypic coefficient of variance was found for number of kernels per row (2.67). moderate (PCV) was the highest in case of grain yield (23.97) followed by dry ear weight (19.70), while lowest phenotypic coefficient of variance was found for number of rows per ear (5.15) and ear length (6.31). Moreover, moderate genotypic coefficient of variation were observed $(\geq 10 \%)$ for fresh ear weight dehusked, while moderate and high ( $20 \%$ and above) phenotypic coefficient of variance were observed for weight of hundred kernels (12.21), ear height (12.28), fresh ear weight dehusked (16.03), dry ear weight (19.70) and grain yield (23.97).

Broad sense heritability $\left(\mathrm{H}^{2}\right)$, an estimate of the total contribution of the genotypic variance to the total phenotypic variance ranged from (7.52\%) to (64.29\%) in Table 3. The highest heritability and high value $(64.29 \%)$ was found for number of husk leaves followed by ear height (60.29\%), moderate heritability estimates were observed for Plant height (51.74\%), fresh ear weight dehusked (46.91) and ear length (39.29).

Table 2. Mean squares from analysis of variance for ten characters in twenty five of maize varieties grown at Shambat winter $07 / 2008$

\begin{tabular}{cccccccccccc}
\hline S.O.V & D.F & PH & EH & FEWD & NHL & DEW & EL & NRE & NKR & $100-W$ & GY \\
\hline Varieties & 24 & $388.59^{* *}$ & $251.38^{* *}$ & $1,252.01^{* *}$ & $2.572^{* *}$ & $463.58^{\text {n.s }}$ & $1.996^{* *}$ & $0.827^{*}$ & $11.58^{\text {n.s }}$ & $6.27^{\text {n.s }}$ & $3,987,158.84^{\text {n.s }}$ \\
Replication & 2 & 548.78 & 178.49 & 884.25 & 0.05 & 61.05 & 2.23 & 1.75 & 21.30 & 48.56 & $5,395,733.85$ \\
Error & 48 & 92.15 & 45.26 & 342.98 & 0.40 & 303.59 & 0.68 & 0.45 & 9.28 & 5.04 & $2,689,904.28$ \\
C.V.\% & & 5.87 & 7.74 & 8.56 & 5.25 & 18.17 & 4.92 & 4.54 & 9.26 & 12.70 & 22.25 \\
\hline
\end{tabular}

PH—Plant height; EH—ear height; FEWD—fresh ear weight dehusked; NHL—number of husk leaves; DEW—dry ear weight; EL—ear length; NRE — number of rows per ear; NKR — number of kernels per row; 100-W—-weight of hundred kernels; GY — grain yield; ns = non significance difference; $^{*}=$ significant at $5 \%$ probability level; ${ }^{* *}=$ significant at $1 \%$ probability level. 
Table 3. Estimation of means, variance components, coefficients of variability, genetic advance and genetic advance as percent of mean of different characters in twenty five varieties

\begin{tabular}{ccccccccccc}
\hline Genetic parameter & PH & EH & FEWD & NHL & DEW & EL & NRE & NKR & $100-W$ & GY \\
\hline Mean & 163.55 & 86.89 & 158.58 & 12.09 & 95.88 & 16.77 & 14.78 & 32.89 & 17.67 & $7,372.72$ \\
GV & 98.81 & 68.71 & 303.01 & 0.72 & 53.33 & 0.44 & 0.13 & 0.77 & 0.41 & $432,418.19$ \\
PV & 190.96 & 113.97 & 645.99 & 1.12 & 356.92 & 1.12 & 0.58 & 10.05 & 5.45 & $3,122,322.47$ \\
EV & 92.15 & 45.26 & 342.98 & 0.40 & 303.59 & 0.68 & 0.45 & 9.28 & 5.04 & $2,689,904.28$ \\
GCV & 6.08 & 9.54 & 10.98 & 7.02 & 9.62 & 3.96 & 4.44 & 2.67 & 3.62 & 8.92 \\
PCV & 8.45 & 12.28 & 16.03 & 8.75 & 19.70 & 6.31 & 5.15 & 9.64 & 12.21 & 23.97 \\
H & 51.74 & 60.29 & 46.91 & 64.29 & 14.94 & 39.29 & 22.41 & 7.66 & 7.52 & 13.85 \\
GA & 14.73 & 13.26 & 24.56 & 1.40 & 5.81 & 8.56 & 0.35 & 5.00 & 3.62 & 504.15 \\
GAM\% & 9.01 & 15.26 & 15.69 & 11.58 & 6.06 & 51.04 & 2.37 & 15.20 & 20.49 & 6.84 \\
\hline
\end{tabular}

GV-Genotypic variance; PV-Phenotypic variance; EV-Environmental variance; GCV-Genotypic coefficient of variation (\%); PCV_-Phenotypic coefficient of variation (\%); $\mathrm{H}^{2}$ — Heritability (\%); GA — Genetic advance; GAM-Genetic advance as percentage of mean; PH—Plant height; EH—ear height; FEWD—fresh ear weight dehusked; NHL—number of husk leaves; DEW—dry ear weight; EL—ear length;

NRE — number of rows per ear; NKR — number of kernels per row; 100-W—weight of hundred kernels; GY — grain yield.

The genetic advance values for ten characters of maize varieties are presented in Table 3. Genetic advance as percent of mean was the highest for ear length (51.04) followed by weight of hundred kernels (20.49), similarly moderate genetic advance observed in fresh ear weight dehusked (15.59), ear height (15.26), number of kernels per row (15.20) and number of husk leaves (11.58), while low Genetic advance was found for Plant height (9.01), grain yield (6.84), dry ear weight (6.06) and number of rows per ear (2.37).

\section{Discussion}

Moderate and high genotypic coefficient of variation and phenotypic coefficient of variation were reported by [17]. The estimated of phenotypic coefficient values were higher than corresponding genotypic coefficient values. According to described by [16]. Result presented in this study and of the reported studies is in agreement with the findings of [18] and [19]. The higher and moderate value of heritability for number of husk leaves, ear height, Plant height, fresh ear weight dehusked and ear length indicates these characters can be used as the genetic parameters for the improvement and selection of higher yielding genotypes and easily be passed from one generation to the next then enhancing the efficiency of selection in maize improvement program. Moderate and high genetic advance were reported by [20]. High values of genetic advance are indicative of additive gene action where as low values are indicative of non-additive gene action. The greater values of genetic advance indicated that ear length, weight of hundred kernels, fresh ear weight dehusked, ear height and number of kernels per row can be used for selecting higher yielding varieties.

\section{Conclusion}

In conclusion, the present study identified the presence of genetic variability among 25 tested varieties. The estimated of phenotypic coefficient values were higher than corresponding genotypic coefficient values. High heritability estimated were observed for number of husk leaves and ear height, moderate heritability estimates were observed for Plant height, fresh ear weight dehusked and ear height. Genetic advance as percent of mean was the highest for ear length and weight of hundred kernel. Hence, the information generated from this study, maize breeder can be exploited for future maize breeding programs.

\section{Acknowledgements}

This paper supported by Agronomy Department faculty of Agriculture Omdurman Islamic University Sudan, we thanks Lab workers for their help us to complete this work.

\section{References}

[1] Rajwade, J. K., Jagadev, P. N., Lenka, D., and Gupta, S. (2018). Correlation and path coefficient studies on elite genotypes of maize inbred lines. Journal of Pharmacognosy.

[2] Shakoor, M. S., Akbar, M., and Hussain, A. (2007). Correlation and path coefficients studies of some morphophysiological traits in maize double crosses. Pak. J. Agri. Sci., 44(2), 213-216.

[3] Elhassan M. A. E. (2004). Effect of Different Irrigation Watering Levels and Genotypes Growth and Yield of Maize (Zea mays L.). Ph.D. thesis, Faculty of Agriculture, Omdurman Islamic University. 
[4] Eltoum, Ahmed, G. (2018). Evaluation of Growth and Yield of Four Maize (Zea mays L.) Cultivars Under Northern Sudan Conditions. Agriculture and Foresty Journal. 2(2), 89-91.

[5] Abdalla, A. E., Mahmoud, M. F., and El Naim, A. M. (2010). Evaluation of some maize (Zea mays l.) varieties in different environments of the Nuba mountain of Sudan. Journal of Applied Sciences Research, 6(12), 6605-6610.

[6] More, A. D., Borkar, A. T. (2016). Analysis of genetic variability, heritability and genetic advance in Phaseolus vulgaris L. International Journal of Current Microbiology and Applied Science, 5: 494-503.

[7] Adhikari, B. N., Shrestha, J., Dhakal, B., Joshi, B. P., and Bhatta, N. R. (2018). Agronomic performance and genotypic diversity for morphological traits among early maize genotypes. International Journal of Applied Biology, 2(2), 33-43.

[8] Sujiprihati, S., Saleh, G. B., and Ali, E. S. (2003). Heritability, performance and correlation studies on single cross hybrids of tropical maize. Asian Journal of Plant Science, 2(1), 51-57.

[9] Poudel, M. R., and Poudel, H. K. (2016). Genetic Variability, Heritability and Genetic Advance of Yield Attributing Traits in Winter Maize. Int. J. Grad. Res. Rev., 1(1), 9-12.

[10] Ogunniyan, D. J., O. Olakojo, S., and K. Ojo, D. (2019). Genetic Variability and Inter-relatedness of Agronomic Traits of Single Cross Hybrid Maize in Contrasting Soil Nitrogen-nutritional Conditions. International Journal of Plant and Soil Science, 29(4), 1-15.

[11] Gomez, K. A. and Gomez, A. A. (1984). Statistical Procedures for Agricultural Research. John Wiley and Sons, New York. P. 680.

[12] Hallauer, A. R., Miranda, J. B. (1988). Quantitative genetics in maize breeding. 2nd ed. Iowa state Universality Press.

[13] Singh, R. K., Chaudhary, B. D. (1979). Biometrical methods in quantitative genetic analysis, Kalyani Publishers.

[14] Subramanian, S. S., Menon, M. (1973). Heterosis and inbreeding depression in rice. Madras Agricultural Journal, $60: 1139$.

[15] Falconer, D. S. (1981). Introduction to quantitive genetics. Longman.

[16] Johnson, H. W., Robinson, H., Comstock, R. (1955). Estimates of genetic and environmental variability in soybeans. Agronomy Journal, 47(7): 314-318.

[17] Ghosh Aditi, Subba Vaskar, Roy Anindita, Ghosh Amitava, and Kundagrami Sabyasachi. (2014). Genetic Variability and Character Association of Grain Yield Components in Some Inbred Lines of Maize (Zea mays L.). Journal of Agroecology and Natural Resource Management, 1(2): 34-39.

[18] Shengu, M. K. (2017). Genetic Study of Some Maize (Zea Mays L.) Genotypes in Humid Tropic of Ethiopia. International Journal of Scientific and Research Publications, 7(1), 281-287.

[19] Tadesse, J., Leta, T., Techale, B., and Lemi, B. (2018). Genetic variability, heritability and genetic advance of maize (Zea mays L.) inbred lines for yield and yield related traits in southwestern Ethiopia. Journal of Plant Breeding and Crop Science, 10(10), 281-289.

[20] Khan, M. H., Ahmad, M., Hussain, M., ul -Hassan, M., and Ali, Q. (2018). Heritability and Trait Association Studies in Maize F1 Hybrids. International Journal of Biosciences, 12(1), 18-26. 